\title{
KESANTUNAN BAHASA JAWA CERAMAH EMHA AINUN NADJIB GREBEG SURA KE 4000 DI COLOMADU TAHUN 2018
}

\author{
Rizka Rahma Pradana \\ Program Studi Magister Pengkajian Bahasa, Program Sekolah Pascasarjana, Universitas Muhammadiyah Surakarta \\ E-mail rizka_pradana.pbsidums@yahoo.com
}

\begin{abstract}
ABSTRAK. Tujuan penelitian menganalisis kesalahan berbahasa Indonesia dalam bidang sintaksis, morfologi, fonologi, dan sosiolinguistik, serta menemukan potensi yang dimiliki penutur. Teknik simak dan catat untuk mengkaji kesalahan bahasa Indonesia terhadap tokoh ulama Emha Ainun Nadjib saat ceramah "Grebeg Sura ke 4000 di Colomadu Karanganyar". Jenis penelitian kualitatif. Metode padan digunakan untuk menganalisis data. Teknik pengujian data menggunakan trianggulasi. Ditemukan kesalahan berbahasa bidang sintaksis berupa kemubadziran kata dan ketidakefektifan kalimat, kesalahan bidang morfologi berupa konfiks, dan bidang fonologi terdapat penggunaan bahasa tidak baku. Secara sosiolinguistis terdapat campur kode dan alih kode. Kesalahan yang mendominasi adalah campur kode. Campur kode merupakan potensi untuk menarik perhatian mitra tutur.
\end{abstract}

Kata kunci: sosiolinguistik; budaya Jawa; kesantunan berbahasa

\section{LANGUAGE PERSONNEL JAVA, EMHA AINUN NADJIB GREBEG SURA TO 4000 IN COLOMADU IN 2018}

\begin{abstract}
The purpose of the study was to analyze errors in Indonesian in the fields of syntax, morphology, phonology, and sociolinguistics, and to discover the potential of speakers. The technique is to see and note to examine the errors of the Indonesian language towards the ulama leader Emha Ainun Nadjib during the lecture "Grebeg Sura to 4000 at Colomadu Karanganyar". Type of qualitative research. The matching method is used to analyze data. Data testing techniques using triangulation. Found language errors in the field of syntax in the form of word slippage and sentence ineffectiveness, morphological errors in the form of confixes, and phonological fields using non-standard language. Sociolinguistically, there is code mixing and code switching. The dominating error is code mixing. Mixing code is the potential to attract the attention of speech partners.
\end{abstract}

Keywords: sociolinguistics; Javanese culture; language politeness

\section{PENDAHULUAN}

Kesalahan berbahasa dipengaruhi oleh kompetensi atau daerah pengetahuan yang dimiliki penutur. Penyimpangan yang sering terjadi bersifat sistematis, konsisten, dan menggambarkan kemampuan peserta didik pada tahap tertentu (yang biasanya belum sempurna) temuan Markhamah dan Sabardila (2011:54-55).

Astuti (2012:445) mengutarakan bahwa bahasa adalah alat yang digunakan untuk berkomunikasi dan menunjukkan identitas masyarakatnya. Hidup dan berkembangnya bahasa ada pada masyarakat karena bahasa digunakan oleh masyarkat.

Fitriyani(2012:136) menyatakan bahwa kebudayaan dan agama sebagai satu rangkaian nilai dan simbol yang saling berhubungan. Kebudayaan agama merupakan ketaatan perilaku manusia terhadap Tuhan. Perilaku manusia yang baik dapat mempengaruhi lingkungannya.

Temuan Gusriani (2012:288) adalah kesantunan berbahasa guru diduga dapat meredam situasi yang kurang nyaman saat terjadi permasalahan dengan siswa. Bahasa yang santun diduga dapat meredam amarah dan rasa kecewa guru pada siswa, dan dapat membuat situasi tetap terkendali.

Hanafi (2014:405) menjelaskan orang menggunakan jauh lebih banyak bentuk standar kepada mereka yang tidak dikenalnya dengan baik dan lebih banyak bentuk vernakuler kepada teman-teman mereka. Hubungan penutur dengan lawan tutur sangatlah penting dan menentukan gaya bertutur yang sesuai.

Mislikhah (2014:295) menyatakan kesantunan merupakan aturan perilaku yang ditetapkan dan disepakati bersama oleh suatu masyarakat tertentu sehingga menjadi prasyarat yang disepakati bersama. Aturan bahasa Jawa disebut tatakrama. Tatakrama itu tercermin dalam tanda verbal.

Menurut Muridan (2007:9) menjelaskan penyebaran Islam di Jawa dengan dua pendekatan. Pendekatan yang dilakukan dengan Islamisasi kultur dan Jawanisasi Islam. Pendekatan tersebut dilakukan untuk menginternalisasikan nilai-nilai Islam di Jawa.

Dikatan oleh Nurjamily (2015:1) bahwa penutur bahasa Indonesia sekarang kurang memperhatikan maksim sopan santun dalam berbahasa. Hal ini disebabkan oleh terbatasnya pengetahuan penutur terhadap prinsip sopan santun dalam berbahasa, prinsip kerja sama dalam berbahasa, dan konteks penggunaan bahasa.

Dalam kaitan dengan kesopanan kedudukan PSS dalam aktivitas berbahasa tidak saja perlu, tetapi sangat penting. Hal itu berkaitan dengan realisasi etika berbahasa. Kesantunan berbahasa dapat direalisasikan 
melalui tindak bahasa memberitahukan, mendeklarasikan, mengekpresifkan, menanyakan, dan memerintah (Prayitno, 2011:206).

Dinyatakan Room (2013:225) bahwa berbicara dengan lemah lembut merupakan prinsip Alquran tentang santun berbahasa. Kesantunan bahasa berporos pada suara yaitu bertutur dengan lemah lembut.

Setiyadi (2012:145) mengungkapkan bahwa bahasa dan masyarakat tidak pernah bisa dipisahkan satu dengan yang lainnya. Di mana ada masyarakat, di situ ada bahasa, dan sebaliknya.

Peneliti Jaya (2013:8) menyatakan kemunculan kebudayaan Islam berasal dari Tuhan. Kebudayaan terbentuk melalui adat istiadat daerah. Kebudayaan semakin berkembang mengikuti perkembangan zaman. Landasan kebudayaan bersumber dari tuntunan ajaran Tuhan.

Penelitian ini menganalisis kesalahan berbahasa Indonesia dalam bidang sintaksis, morfologi, fonologi, sosiolinguistik, dan kata interogatif serta menemukan potensi yang dimiliki penutur pada "Kesantunan Berbahasa Jawa dalam Ceramah Emha Ainun Nadjib Grebeg Sura ke 4000 di Colomadu Tahun 2018”.

\section{METODE}

Jenis data berupa kualitatif yang diteliti berhubungan secara langsung dengan narasumber tanpa merubah hasil yang ditemukan di lapangan. Pendapat Sugiyono (2012:14) menjelaskan jenis kualitatif berupa penelitian yang alamiah tanpa mengurangi atau menambahi dari sumbernya. Lokasi penelitian dilaksanakan di Desa Baturan lapangan Colomadu, Kabupaten Karanganyar. Penggunaan teknik simak dan catat pada analisis data ini bertujuan untuk memperoleh hasil objek secara langsung. Objek penelitan berupa penggunaan bahasa lisan oleh Ustadz Emha Ainun Nadjib. Mahsun (2013:9293) menyatakan untuk memperoleh data menggunakan teknik simak dan catat. Metode padan digunakan untuk menganalisis kata, frasa, klausa, dan kalimat yang terdapat dalam tuturan informan (kesalahan berbahasa Ustadz Emha Ainun Nadjib). Trianggulasi untuk menguji keabsahan data. Peneliti juga mentransformasikan hasil rekaman data.

\section{HASIL DAN PEMBAHASAN}

Temuan data analisis kesalahan berbahasa pada penelitian ini diklasifikasikan dari beberapa bidang, yakni bidang sintaksis, morfologi, fonologi, sosiolinguistik, dan kata interogatif. Berikut penjelasan kesalahan berbahasa masing-masing bidang.

\section{Analisis Kesalahan Berbahasa}

Sintaksis merupakan cabang linguistik yang membahas susunan kata-kata dalam suatu kalimat (Verhaar,
2012:11). Analisis kesalahan berbahasa dalam sintaksis berupa struktur kalimat, kelogisan, urutan kata, kohorensi (kepaduan), kevariasian, dan keserasian antar kalimat. Temuan penelitian kesalahan bidang sintaksis dinyatakan berikut ini.

(1) Bapak ibu hadirin dan jamaah rahmatulloh, acara selanjutnya yaitu sinau bareng bersama Cak Nun dan Kyai Kanjeng... .(MC.GS.40)

(2) ...tepuk tangan untuk Desa Baturan yang pertama tahun 2014 Cak Nun dan Kyai Kanjeng persis di lapangan ini dan alhamdulillah pada ke dua kalinya di tahun 2018 genap 4000 pergelaran cak Nun dan Kyai Kanjeng juga ada di sini. (MC.GS.40)

(3) Saya nyatakan cinta saya dunia akhirat kepada semua yang bisa saya pandang wajah anda maupun yang tidak bisa saya lihat di belakang-belakang,... . (mubazir dan ambigu) (CN.Ust.60)

(4) ...kalau memang kalian cinta kepadaku maka caranya untuk bercinta padaku adalah ikutilah jejakku begitulah kata Rosullah Sholallahu Alaihi Wassalam. (CN.Ust.60)

(5) Jadi malam hari ini kita sinau bareng, termasuk awal tadi kita menyanyikan Indonesia Raya kemudian kita membaca Pancasila kemudian kita melaksanakan grebeg sura satu Muharom awal dari Tahun Hijriah setiap tahun dan ini sudah 14 kalinya di Batur Colomadu Alhamdulillahirobilalamiin inggih Baturan. (CN.Ust.60)

(6) Wes ana kyai aku ura lulus sebagai kyai dadi aku ura nduwe ketepatan atau mahkom untuk ngulang njenenganwes onosarjana, wes ana dokter, wes ana sekolah pesantren lak aku ora karone wani ngulang karena aku tidak punya ilmu yang unggul dari anda semua mulane aku wanine sinau bareng, nduk koe sakdurengi rabi lak mbok sinauni to wong lanang kae? (CN.Ust.60)

(7) wes rapopo sing penting wes ngerti prinsip-prinsipe aku ngerti cah lanang kae nasab oke, akhlak oke ibadhe oke yo lumayan duite ora banget-banget kerene ya gitukan ya. (CN.Ust.60)

(8) Mengke kula aturi bapak-bapak sedaya para kyai, para pengurus $\mathbf{N U}$, para sesepuh, pak Kapolsek, pak Danramil dan semuanya untuk melu nata kendurene ilmu. (CN.Ust.60)

Kesalahan berbahasa pada nomer (1, (2), (3) merupakan kesalahan kemubaziran dan ketidakefektifan kalimat. Pada nomer (1) Bapak ibu hadirin dan jamaah termasuk kalimat mubazir seharusnya menggunakan salah satu kata berupa hadirin karena mencangkup semua peserta yang hadir. Sedangkang nomer (2) tepuk tangan untuk Desa Baturan seharusnya tepuk tangan untuk warga Desa Baturana karena tepuk tangan ditujukan 
untuk warga yang tinggal di Desa Baturan. Pada nomer (3) kata Saya nyatakan cinta saya dunia akhirat kepada semua yang bisa saya pandang terdapat kemubaziran kalimat, seharusnya penggunaan kata saya cukup satu kali di awal kalimat menjadi saya nyatakan cinta dunia akhirat kepada semua yang bisa dipandang. Pada nomer (4) penulisan ku mengalami kemubaziran terjadi pada kalimat ini seharusnya cukup satu menjadi Kalau memang kalian cinta kepada Rosulloh Sholalluhu Alaihi Wassalam maka ikutilah jejakku. Pada nomer (5)Penggunaan kata kemudian berkali-kali mengakibatkan kalimat ini menjadi tidak efektif. Seharusnya Jadi malam hari ini kita sinau bareng termasuk awal tadi kita menyanyikan Indonesia Raya kemudian kita membaca Pancasila lalu kita melaksanakan grebeg sura satu. Pada nomer (6) pada kalimat tersebut kata wes ana merupakan bahasa Jawa yang artinya sudah ada. Kata wes ana tidak perlu ditulis sampai tiga kali sehingga membuat kalimat ini menjadi mubadzir. Pada nomer (7) wes rapopo sing penting wes ngerti prinsip-prinsipe aku ngerti cah lanang kae nasab oke, akhlak oke ibadhe oke yo lumayan duite ora bangetbanget kerene ya gitukan ya. Terjadi kemubadziran pada kalimat ini karena kata oke berulang sampai tiga kali dan kata ya dua kali. Seharusnya cukup satu kata oke dan ya. Pada nomer (8) para yang terdapat pada kalimat di atas mengakibatkan kalimat menjadi mubadzir seharusnya kata para cukup di awal kalimat karena kata para lebih dari satu. Selain kemubaziran terdapat singkatan NU yang memiliki arti Nadatul Ulama merupakan kelompok atau golongan majelis dzikir dan sholawat.

Temuan Mutiadi (2016:7) menjelaskan kesalahan sintaksis berupa kesalahan penyusunan struktur kalimat, penggandaan subjek, campur kode, dan alih kode. Kesalahan sintaksis tersebut mendominasi pada penelitian. Persamaan dengan penelitian ini membahas mengenai kesalahan dibidang sintaksis ketidakefektifan kalimat. Perbedaan terhadap penelitian ini mengenai kesalahan pada penggandaan subjek.

\section{Morfologi}

Morfologi sebagai cabang ilmu bahasa yang membahas mengenai struktur pembentuk kata atau morfem. Kesalahan pada bidang morfologi berupa analisis kesalahan yang penggunaan morfem, kata, dan proses penambahan afiks (berupa prefiks, infiks, surfiks, dan konfiks), proses reduplikasi atau perulangan, dan penggabungan kata. Adapun temuan mengenai kesalahan bidang morfologi di bawah ini.

(9) Maka Alloh kemudian titip pesan pada kekasihnya Kanjeng Nabi Muhammah Sholalluhu Alaihi Wassalam yang ditulis dalam Al-Quran inkuntum tuhibul yuhtikumulloh fatabiuni yuhkibumulloh. (CN. Ust.60)
Kesalahan pada nomer (9) kata titip secara morfologi belum tepat seharusnya mendapat imbuhan konfiks awalan meN- dan akhiran -kan menjadi menitipkan.

Peneliti Mutiadi (2016:7-8) menjelaskan kesalahan dibidang morfologi banyak terjadi karena menghilangkan imbuhan pada suatu kata dan penyingkatan morfem. Kesalahanpenggunaan bahasadaerahberupapembentukan kata kerja yang disingkat. Hal ini menimbulkan kesalahan dalam bidang morfologi. Persamaan dengan penelitian ini membahas mengenai kesalahan morfologi pada penyingkatan morfem karena bahasa daerah yang mempengaruhi. Sedangkan perbedaan pada penelitian ini penyingkatan penggunaan bahasa daerah.

\section{Fonologi}

Fonologi sebagai salah satu cabang ilmu bahasa yang membahas mengenai bunyi bahasa tertentu berdasarkan fungsinya. Kesalahan berbahasa pada fonologi meliputi penggunaan huruf yang tidak baku. Adapun temuan mengenai kesalahan bidang fonologi di bawah ini.

(10) cambuk yang membuat jiwamu menjadi hantu suami dan istri tak saling mengabdi tak mengalahkan atau memenangkan keduanya adalah sahabat bergandengan tangan bersama-sama mengarungi jejak. (CN.Ust.60)

(11) nduk koe sakdurengi rabi lak mbok sinauni to wong lanang kae? (CN.Ust.60)

(12) Kita sudah punya tema beberapa tapi kita sinau bareng, (CN.Ust.60)

(13) Ketika kita sudah berumahtangga masih mempelajari suami dan istri ndak? (CN.Ust.60)

Kesalahan penulisan pada nomer (10) dan (11) kata istri dan koe secara fonemis [isteri] dan [kowe]. Pada nomer (12) dan (13) kata tapi dan ndak termasuk kata tidak baku dalam bahasa Indonesia penulis memerhatikan kaidah kebahasaan terutama bahasa baku. Jadi penulisan yang baku kata tetapi dan tidak.

Hasil analisis Nuryadi (2010:80) menjelaskan ragam bahasa dipengaruhi oleh situasi pemakaian bahasa yang digunakan oleh masyarakat secara berdampingan. Ragam pokok bahasa berupa ragam tinggi (formal style) dan kesusasteraan yang berasal dari masyarakat. Persamaan dengan peneliti mengkaji ragam bahasa daerah. Perbedaan dengan hasil penelitian peneliti menganalisis situasi ragam pokok bahasa.

\section{Sosiolinguistik}

Rohmadi (2010:12) menjelaskan sosiolinguistik adalah ilmu bahasa yang membahas mengenai kebahasaan dengan hubungannya dengan faktor-faktor sosial, situasional, dan kultural. Kesalahan bidang sosiolinguistik 
meliputi alih kode dan campur kode. Peralihan bahasa daerah ke bahasa Indonesia atau sebaliknya yang dipengaruhi oleh situasi tertentu disebut alih kode. Sedangkan campur kode yaitu penggunaan dua bahasa secara bersamaan dipengaruhi oleh latar belakang penutur.

Kesalahan tersebut pada penggunaan kata yang dicampurkan antara bahasa Indonesia dan bahasa daerah atau bahasa Inggris. Kesalahan bidang sosiolinguistik ditemukan di bawah ini.

(14) Bapak Ibu hadirin rahmatulloh memecah mengutuhkan kerja dan fungsi memecah manusia sujud sembahyang mengutuhkannya. (CN.Ust.60)

(15) Tuhan kala hari esok jangan di makan cinta di kandungan cakrawala kalau cemas di iming-imingi tetangga berkacalah pada sunyi 1987 oleh Emha Ainun Nadjib atau Cak Nun. (CN.Ust.60)

(16) Bapak ibu hadirin dan jamaah rahmatulloh, acara selanjutnya yaitu sinau bareng bersama Cak Nun dan Kyai Kanjeng... . (CN.Ust.60)

(17) Untukituyang terhormat CakNun dan Kyai Kanjeng waktu sepenuhnya kita haturkan sumonggo. (CN. Ust.60)

(18) Maka Alloh kemudian titip pesan pada kekasihnya Kanjeng Nabi Muhammad Sholalluhu Alahi Wassalam yang ditulis dalam Al-Quran inkuntum tuhibul yuhtikumulloh fatabiuni yuhkibumulloh. (CN.Ust.60)

(19) Kangenkan pengen ketemu maka Alloh mengatakan famayyanju niko arobi falmayyakmal amalan sholika barang siapa yang menginginkan pertemuan denganku maka berbuatlah baik. (CN.Ust.60)

(20) Nek tresna mesti outputnya kengen inggih boten?(CN.Ust.60)

(21) Jare biyen arep brontak arep melu gabung Solo apa Sukoharjo saiki dalane wes didadani ora sida alhamdulillahirobilalamiin inggih alhamdulliah pokoke bengi iki muga-muga iki mau aku lewat kono ya Alloh wong sakmeneki akahi jan-jane dorene ki sing diparani sapa? (CN.Ust.60)

(22) InsyaAlloh berkahnya lebih tinggi daripada yang tinggal di kabupatennya sendiri ngoten inggih kirakira. (CN.Ust.60)

(23) Mengke kula aturi bapak-bapak sedaya para kyai, para pengurus NU, para sesepuh, pak Kapolsek, pak Danramil dan semuanya untuk melu nata kendurene ilmu pada malam hari ini. (CN.Ust.60)

(24) Tuhan kala hari esok jangan dimakan cinta di kandungan cakrawala kalau cemas diiming-mingi tetangga berkacalah pada sunyi 1987 oleh Emha Ainun Nadjib atau Cak Nun. (CN.Ust.60)

(25) tapi jangan khawatir ilmu kuwi bermacam-macam ada yang tumbuh cepat, ada yang langsung tumbuh. (CN.Ust.60)
(26) Ketika kita sudah kawin perak 25 tahun isi sinau ora? (CN.Ust.60)

(27) Ketika uwes seket tahun masih belajar dan soyo suwe angel dipelajari jebul wong lanang wedok ngonten inggih.(CN.Ust.60)

(28) Pulau Colomadu pulau ya la kabupatene neng kidul e la ki neng kene dewe gih ta? (CN.Ust.60)

(29) Jare biyen arep brontak arep melu gabung Solo apa Sukoharjo saiki dalane wes didadani ora sida alhamdulillahirobilalamiin inggih alhamdulliah pokoke bengi iki muga-muga iki mau aku lewat kono ya Alloh wong sakmeneki akahi jan-jane dorene ki sing diparani sapa? Apa ta? (CN.Ust.60)

(30) Nek tresna mesti outputnya kengen inggih boten? (CN.Ust.60)

(31) Bangsa Indonesia umat manusia dan setiap manusia merindukan sesuatu yang sejati dan tidak akan pernah bertemu itu namanya asshirot almustakim anda melalui sabil kemudian anda menempuh syarik kemudian anda juga menjalankan thorik ya untuk mencapai shirot almustakim. (CN.Ust.60)

(32) Masalahnya adalah we ki kangen kara sapa? cinta nang sapa? (CN.Ust.60)

(33) Jadi aku adalah tetanggamu, kalau aku mengatakan kau cantik, engkau hebat, itu sungguh-sungguh karena engkau cantik dan hebat ngono ya. (CN. Ust.60)

(34) Ya Alloh malam ini kita berkumpul untukmu fasaha bi ma fisama watiwalard wahual azizulkhakim ojo ana siang yang kita lewati tanpa bertasbih kepada Alloh, ojo ana bengi yang bertasbih kepada Alloh, ojo nyekel apa-apa yen ora mbok jak bertasbih kepada Alloh. (CN.Ust.60)

(35) Aku lak meng tanggamu tangga kuwikan kowe luweh percaya ngene nak enek cah ayu ki jare sabrange nek ana cah ayu wes ana wong loro seng ngarani cah iki ayu. (CN.Ust.60)

Data (15) dan (24) ditemukan campur kode pada kata iming-imingi memiliki arti sesuatu untuk membujuk (memikat hati). Data (16) sinau bareng artinya memiliki arti belajar bersama. Jadi sianu bareng memiliki arti belajar bersama. Pada data (17) ditemukan campur kode haturkan sumonggo. Haturkan memiliki arti memberikan, sumonggo memiliki arti mempersilahkan. Jadi kata haturkan sumonggo berati memberikan waktu atau mempersilahkan pembicara. Data (20) temuan alih kode dan campur kode, alih kode berupa Nek tresna mesti,kengen inggih boten? memiliki arti apabila cinta pasti, rindu ya tidak? pertanyaan untuk perasaan yang terdapat di hari, sedangkan campur kode bahasa Inggris dengan bahasa Indonesia berupa outputnya berarti keluarnya.

Pada data (21) ditemukan campur kode, berupa Jare 
biyen arep brontak arep melu gabung Solo berarti katanya dahulu ingin melawan ingin ikut, lewat kono berarti melalui sana, wong sakmeneki akahi jan-jane dorene ki sing diparani sapa? berarti manusia sebanyak ini sebenarnya mau kesini siapa yang didatangi?, sedangkan campur kode dengan alhamdulillahirobilalamiin berarti ungkapan rasa syukur atas nikmat yang diberikan Alloh. Temuan campur kode pada data (22) berupa ngoten inggih kira-kira berarti begitu ya kira-kira sebagai ungkapan memperkirakan. Data (23) temuan campur kode berupa Mengke kula aturi berarti nanti saya persilahkan. Data (25) temuan campur kode kata kuwi berarti itu. Data (26) temuan campur kode kata sinau ora berarti belajar tidak beratnya terhadap mitra tutur. Pada data (27) temuan campur kode berupa uwes seket tahun menjelaskan umur lima puluh tahun, soyo suwe angel memiliki arti semakin lama sulit dipelajari, jebul wong lanang wedok ngonten inggih data ini berarti ternyata orang laki-laki perempuan sama ya. Data (28) temuan data campur kode pada kalimat kabupatene neng kidul e la ki neng kene dewe gih ta? berarti kabupatennya berada di selatan la ini berada disini sendiri ya?

Temuan alih kode pada data (14) dan (16) pada kata rahmatulloh memiliki arti mendapat rahmat dari Alloh SWT. Temuan data (18) Sholalluhu Alahi Wassalam sebagai gelar untuk sanjungan nabi Muhammad dan inkuntum tuhibul yuhtikumulloh fatabiuni yuhkibumulloh termasuk alih kode menjelaskan doa yang terdapat di Al Quran yang dimaksud untuk kalau memang kalian cinta kepada ku maka ikutilah jejak yang diajarkan rosullah. Pada data (19) terdapat alih kode bahasa Arab yang ditafsirkan ke bahasa Indonesia berupa famayyanju niko arobi falmayyakmal amalan sholika diartikan barang siapa yang menginginkan pertemuan denganku maka berbuatlah baik. Data (31) temuan berupa alih kode asshirot almustakim, syarik, dari thorik penggunaan bahasa Arab. Analisis campur kode data (32) berupa we ki kangen kara sapa? cinta nang sapa? berarti kamu itu rindu dengan siapa? cinta dengan siapa? ditujukan kepada mitra tutur bertanya mengenai rindu dan cinta terhdap siapa setiap orang. Pada data (33) merupakan campur kode berupa kata ngono ya berarti begitu ya. Data (35) termasuk campur kode berupa ngene nak enek cah ayu ki jare sabrange nek ana cah ayu wes ana wong loro seng ngarani cah iki ayu berarti begini apabila ada wanita cantik yang menyampaikan sabrange (bahasa daerah penutur) apabila ada yang menyatakan dua orang wanita ini cantik.

Penelitian Suryadi (2015:2) menjelaskan bahasa di Semarang dipengaruhi oleh masyarakat multilingual. Situasi ini selain berdampak pada posisi bahasa Jawa juga berdampak pada warna penggunaan tuturan Jawa. Sedangkan temuan Marmanto (2017:143) menjelaskan pada umumnya masyarakat dalam berkomunikasi menggunakan dua bahasa atau lebih (bilingual) sesuai dengan partisispan, topik, dan situasinya. Fenomenanya saat ini banyak dari mereka yang menguasai dua bahasa bahkan lebih, yakni bahasa pertama (bahasa ibu) dan bahasa kedua. Persamaan dengan peneliti penggunaan bahasa Jawa yang melatarbelakangi. Perbedaan analasis data peneliti tidak mengkaji alih kode.

\section{Kata Interogatif}

Semua bahasa mempunyai cara khusus untuk menyampaikan informasi. Penyampaian informasi dapat dilakukan melalui pertanyaan. Dalam ilmu bahasa bentuk pertanyaan itu berkaitan dengan perihal konstruksi interogatif. Temuan Tarmini (2009:77) meneliti mengenai konstruksi interogatif tertutup hanya ditemukan tiga kata tanya, yaitu kata tanya apa, apakah, dan bagaimana. Letak urutan kata tanya di dalam kalimat cenderung menempati posisi di depan atau di awal kalimat. Kata tanya dalam konstruksi interogatif tertutup tidak mengisi atau menggantikan fungsi sintaksis. Oleh karena itu, pelesapan kata tanya dengan intonasi tertentu dapat dilakukan tanpa mengubah informasi yang ditanyakan. Berikut kata interogatif yang terdapat penelitian ini.

(36) Ketika kita sudah kawin perak 25 tahun isi sinau ora? (CN.Ust.60)

(37) pulau Colomadu pulau ya la kabupatene neng kidul e la ki neng kene dewe gih ta?(CN.Ust.60)

(38) Jare biyen arep brontak arep melu gabung Solo apa Sukoharjo saiki dalane wes didadani ora sida alhamdulillahirobilalamiin inggih alhamdulliah pokoke bengi iki muga-muga iki mau aku lewat kono ya Alloh wong sakmeneki akahi jan-jane dorene ki sing diparani sapa? apa ta?(CN.Ust.60)

(39) lo sapa seng pengen ketemu kajaba wong seng kangen inggih boten? sapa seng kangen kajaba wong seng tresna betul nggak?(CN.Ust.60)

(40) Masalahnya adalah we ki kangen kara sapa? cinta nang sapa?(CN.Ust.60)

(41) karo pemimpinmu kowe yo wes mantep gari aku meng kancamu meng tetanggamu kan gitu inggih boten? (CN.Ust.60)

Temuan data pada nomer (36), (37), (38), (39), (40), dan (41) sebagai temuan kata introgatif berupa kalimat tanya. Pada data nomer (36) berupa kata sinau ora? berarti menanyakan belajar tidak?. Data nomer (37) berupa kene dewe gih ta? berarti menanyakan berada ada disini sendiri ta (keberadaan). Data nomer (38) beruapa kata sapa ? apa ta?berarti menanyakan siapa (nama orang) apa (kegiatan yang dilakukan). Data nomer (39) dan (41) inggih boten? berarti menanyakan kepastian, sedangkan betul nggak? berarti menanyakan kebenaran. Data nomer (40) berupa kangen kara sapa? cinta nang sapa? berarti menanyakan rindu dan cinta. 
Peneliti Suparjo (2008:2-50) menjelaskan kesalahan kata introgatif mengenai strategi kebudayaan Walisongo menggunakan instrumen kebudayaan lokal tersebut untuk mempromosikan nilai-nilai Islam. Persamaan dengan peneliti mengenai analisis instrumen budaya lokal dan agama. Perbedaan dengan peneliti menganalisis mengenai tatanan sosial Masjid.

\section{Potensi yang dimiliki penutur}

Potensi sebagai kelebihan yang dimiliki oleh penutur dan merupakan ciri khas seseorang.

1. Bahasa yang digunakan pembicara dapat menghidupkan suasana dengan interaktif dengan mitra tutur.

2. Penyajian materi yang dibawakan pembicara dapat membawa mitra tutur atau pendengar memahami maksud penutur karena mayoritas berasal dari Jawa.

3. Penutur merendahkan hati atas kemampuan yang dimiliki dengan bahasa mengajak mitra tutur untuk belajar bersama.

Gunawan (2013:18) mengungkapkan bahwa kesantunan berbahasa berkaitan dengan kesopanan perilaku. Kesantunan saling berkaitan antara bahasa dan perilaku. Kesantunan berbahasa merupakan hal mutlak yang dibutuhkan dalam berkomunikasi. Persamaan dengan penelitian ini potensi diri dari penutur melalui kesantunan bahasa yang digunakan untuk berinteraksi sosial. Perbedaan terhadap peneliti pada analisis penggunaan bahasa.

\section{SIMPULAN}

Berdasarkan hasil analisis ditemukan kesalahan berbahasa pada bidang sintaksis, morfologi, fonologi, sosiolinguistik, dan kata interogatif. Kesalahan bahasa bidang sintaksis meliputi kemubaziran dan ketidakefektifan kalimat yang disampaikan penutur. Kesalahan bahasa bidang morfologi pada penelitian ini penggunaan imbuhan konfiks awalan (meN-) dan akhiran (-kan). Kesalahan bahasa bidang fonologi berupa kaidah penggunaan bahasa baku. Kesalahan bidang sosiolinguistik menyangkut pemilihan kata yang dicampurkan antara bahasa Indonesia dan bahasa daerah atau campur kode. Kesalahan kata introgatif, penutur tidak menggunakan kata tanya diawal tuturan seperti kata tanya apa, apakah, dan bagaimana.

Potensi yang dimiliki penutur bahasa yang digunakan dapat menarik lawan tutur untuk memperhatikan ceramah yang disampaikan. Penggunaan bahasa penutur dan mitra tutur dapat berlangsung secara baik karena kesamaan budaya. Selain hal tersebut potensi yang dimiliki penutur tidak ingin menunjukan kelebihan yang dimiliki. Penutur merasa dirinya sebagai orang biasa unagkapan berapa tetanggamu sebagai bentuk bahwa derajatnya sama dengan mitra tutur.

\section{DAFTAR PUSTAKA}

Astuti, R (2012). Kesantunan Berbahasa dalam Talkshow "Neo Democrazy" di Metro TV. Jurnal MARKAH (Pendidikan Bahasa dan Sastra Indonesia), 1, (1), 426-514.

Fitriyani. (2012). Islam danKebudayaan. Jurnal Al- Ulum, $12,(1), 129-140$.

Gunawan, F. (2013). Wujud Kesantunan Berbahasa Mahasiswa Terhadap Dosen di Stain Kendari: Kajian Sosiopragmatik. Journal Arbitrer, 1, (1), 8-18.

Gusriani, N. (2012). Kesantunan Berbahasa Guru Bahasa Indonesia dalam Proses Belajar Mengajar di SMA Negeri 2 Lintau Buo. Jurnal Pendidikan Bahasa dan Sastra Indonesia, 1, (1), Seri B 87.

Hanafi, M. (2014). Kesantunan Berbahasa dalam Perspektif Sosiolinguistik. Jurnal Ilmu Budaya, 2, (2), 399-406.

Jaya. (2013). Islam dan Kebudayaan Islami. AT-TA'LIM, 4, Diakses Jurnal Indonesian Publication Index (IPI) diakses 16 Oktober 2018

Mahsun. (2013). Metode Penelitian Bahasa Tahapan Strategi, Metode, dan Teknik. Jakarta: PT. Raja Grafindo Persada.

Markhamah \& Sabardila, A. (2011). Analisis Kesalahan dan Karakteristik Bentuk Pasif. Solo: Jagat Abjad.

Marmanto, S. (2017). Alih Kode dalam Interkasi di Lingkungan Pondok Pesantren Ulil Albaab: Kajian Sosiolinguistik". Cendekia, 11, (2), 143-158.

Muridan. (2007). Islam dan Budaya Lokal: Kajian Makna Simbol dalam Perkawinan Adat Keraton. P3M STAIN Purwokerto: Ibda '(Jurnal Studi Islam dan Budaya), 5, (1).

Mutiadi, A.D. (2016). Analisis Kesalahan Morfologis dan Sintaksis Pada Pidato Presiden Joko Widodo Periode Januari 2015. Jurnal Fon, 6, (1), 1-8

Mislikhah, ST. (2014). Kesantunan Berbahasa. Ar-Raniry: International Journal of Islamic Studies. 1, (2), 285 296.

Nurjamily, W.O. (2015). Kesantunan Berbahasa Indonesia dalam Lingkungan Keluarga (Kajian Sosiopragmatik). Jurnal Humanika, 3, (15), 1-18

Nuryadi. (2010). Bahasa dalam Masyarakat: Suatu Kajian Sosiolinguistik. Jurnal Makna, 1. (2), 75-84.

Prayitno, H.J. (2011). Teknik dan Strategi Tindak Kesantunan Direktif di Kalangan Andik SD Berlatar Belakang Budaya Jawa. Jurnal Kajian Linguistik dan Sastra, 23, (2), 204-218 
Rohmadi, M. (2010). Pragmatik: Teori dan Analisis. Surakarta: Yuma Pustaka.

Room, R. (2013). Konsep Kesantunan Berbahasa dalam Islam. Jurnal Adabiyah, XIII, (2), 223-234

Setiyadi, D. (2012). Peranan Sosiolinguistik dalam Pengajaran Bahasa: Sebuah Kajian Teoretis dan Penerapannya (Temuan Linguistik Untuk Pengajaran Bahasa). Premiere Educandum: Jurnal Pendidikan Dasar dan Pembelajaran, 20, (02), 145-157.

Sudaryanto. (2013). Metode dan Aneka Teknik Analisis Bahasa: Pengantar Penelitian WahanaKebudayaan secara Linguistis. Yogyakarta: Sanata Dharma University Press.
Sugiyono. (2012). Metode Penelitian Kuantitatif Kualitatif dan R\&D. Bandung: Alfabeta.

Suparjo. (2008). Islam dan Budaya: Strategi Kultural Walisongo dalam Membangun Masyarakat Muslim Indonesia. KOMUNIKA, 2, (2), 178-193.

Tarmini, W. (2009). Kata Tanya dalam Konstruksi InterogatifBahasa Indonesia: Kajian Sintaktis dan Semantis". Sosiohumaniora, 11, (1), 77-92.

Verhaar, J.W.M. (2012). Asas-Asas Linguistik Umum. Yogyakarta: Gadjah mada University Press. 